\title{
Sırt Ağrısı ve Vücut Duruşu Değerlendirme Aracı: Türkçe Geçerlik ve Güvenirlik Çalışması
}

\author{
Dercan Gençbaş ${ }^{1} \oplus$, Hatice Bebiş ${ }^{\circledR}$
}

'Atılım Üniversitesi Sağlık Bilimleri Fakültesi, Hemşirelik Bölümü, Ankara, Türkiye

${ }^{2}$ Yakın Doğu Üniversitesi, Sağlık Bilimleri Fakültesi, Lefkoşa, Kuzey Kıbrıs TC

Dercan Gençbaş, Dr. Öğr. Üyesi Hatice Bebiş, Doç. Dr.

İletişim:

Dr. Öğr. Üyesi Dercan Gençbaş Atılım Üniversitesi Sağlık Bilimleri Fakültesi, Hemşirelik Bölümü, Ankara, Türkiye Tel: +9003125866102

E-Posta:dgencbas@gmail.com

Gönderilme Tarihi : 16 Ekim 2017

Revizyon Tarihi : 28 Kasım 2017

Kabul Tarihi : 30 Kasım 2017
ÖZET

Amaç: Adölesanların vücut duruşu ve sırt ağrısı gibi sorunlarını ölçmek için nitel veri araçları nadir bulunmaktadır. Bu bağlamda, bu çalışmada Portekiz'de geliştirilen Sırt Ağrısı ve Vücut Duruşu Değerlendirme Aracı'nın Türkçe'ye uyarlanması amaçlanmıştır.

Yöntem: Bu çalışma metodolojik olarak planlanmıştır. Araştırmanın evrenini bir ortaokulda öğrenim gören 139 öğrenci oluşturmaktadır. Ölçek uyarlamasında geçerlilik çalışması için dil, kapsam, yapı ve ölçüt geçerliliği; güvenirlik için ise zamana göre değişmezlik analizleri yapııııştır. Etik kurul onayı ve kurum izni alınmıştır.

Bulgular: Araç Türkçe'ye çevrildikten sonra alınan uzman görüşleri ile elde edilen Kapsam Geçerlilik Indeksi 90.8 olarak oldukça yüksek bulunmuştur. Ölçüt geçerliliği için "Visual Analoge Scale (VAS)" kullanıııııștır. Sırt Ağrısı ve Vücut Duruşu Değerlendirme Aracı' $ı$ ın skoru ile VAS skoru arasındaki korelasyon katsayısı $r=-.684$ şeklinde hesaplanmıştır $(p=.000)$. Tekrarlanabilirliği test etmek için, aracın son hali iki hafta sonra 91 öğrenciye tekrar uygulanmıştır. Araçtaki 1'den 20'ye kadar olan sorularda yapılan kappa analizine göre, 3 soru "orta", 15 soru "iyi", 3 soru da "çok iyi" derecede uyumlu olarak sınıflandırılmıştır. Test-tekrar test arasında istatistiksel olarak anlamlı bir fark saptanmamışıı $(Z=-.127, \mathrm{p}=.899)$.

Sonuç: Sonuç olarak, Sırt Ağrısı ve Vücut Duruşu Değerlendirme Aracı Türk adölesanlar için geçerli ve kullanılabilir bir araçtır.

Anahtar sözcükler: Adölesan, ağrı, vücut duruşu, sağılık, hemşireler

THE VALIDITY AND RELIABILITY OF THE TURKISH VERSION OF BACK PAIN AND BODY POSTURE EVALUATION INSTRUMENT (BACKPEI)

\section{ABSTRACT}

Purpose: Qualitative data tools are rarely used? to measure adolescents' body posture problems such as back pain. In this context, evaluation of adaptation of the Turkish version of BackPEl which was developed in Portugal is intended in this study.

Methods: This study was planned as a methodological one. The sample of the study consisted of 139 students. For validity in the scale, adaptation was carried out with language, scope, structure and criterion validity; for reliability in the scale, adaptation was carried out with? stability analysis according to time. Ethics Committee Confirmation and corporate permission has been received.

Results: The Content Validity Index obtained with expert opinions after translating the tool to Turkish and it was found to be as high as 90.8 . Criterion validity "Visual Analogue Scale (VAS)" was used. Spearman's correlation coefficient between BackPEI and VAS score was $r=-.684(p=.000)$. To test its reproducibility, the final version of the BackPEl was applied to 91 schoolchildren on two distinct occasions (test and re-test), separated by a 2-week interval. According to the kappa coefficient for questions 1-20 in the questionnaire, 3 were classified as "moderately fit", 15 as "good"and 3?? as "very good". The difference between the test-retest was not statistically significant $(Z=-.127 . p=.899)$.

Conclusions: Finally, it can be concluded that the BackPEI constitutes a valid and reproducible instrument for Turkish adolescents.

Keywords: Adolescent, pain; posture, health, nurses 
on zamanlarda, bir halk sağlığı sorunu haline gelen sırt ağrısı probleminin önemsenmemesi, sorunun tespiti ve çözümü için bir bariyer olarak önümüze çıkmaktadır $(1,2)$. Bel ağrısı prevelansı bilinenin aksine çocukluk ve adölesan çağlarında artmaktadır. Adölesan döneminde okul öncesi döneme göre daha sık bel ağrısı görülmektedir. Bu sıklık \%30'lara kadar ulaşmaktadır (3-5).

Adölesan dönemde sırt ağrısı gelişme riski cinsiyet, yaş, yoğun fiziksel aktivite, sigara kullanmak, anksiyete ve depresyon, ailede sırt ağrısı varlığı gibi multifaktöriyel nedenlere bağlıdır (1). Ancak okuldaki çevresel faktörlerin de bu dönemdeki sırt ağrılarında oldukça etkili olduğu görülmektedir. Bunlar, okuldaki hareketsiz yaşam, uzun oturma süreleri, günümüzde bilgisayar kullanımının artması, ağır ve yanlış çanta taşıma alışkanlıkları, bu çağın getirdiği duruş bozuklukları ve bu yaşta gelişebilen kifoz, skolyoz, kanat skapula gibi omurgayı ilgilendiren şekil bozuklukları sıralanabilir. Ayrıca okuldaki masa ve sıraların ergonomik koşullara uygun olmaması da adölesan çağ bel ağrılarında büyük rol oynamaktadır (7-9). Bu konuda yapılan bir çalışmada, okuldaki masa ve sıraların ergonomik olarak düzenlenmesi sonucunda abdominal ve sırt kas gelişimi düzeltildiği ve sırt ağrılarının azaldığı belirtilmiştir (9). Yao, Luo, Ai ve Chen (2012) yaptıkları çalışmada, düzenli oturma pozisyonuna sahip olan, düzenli basketbol oynayan, jimnastik yapan adölesanlarda, sırt ağrısı diğerlerine göre daha düşük saptandığını rapor etmiştir (10).

Sırt ağrısı semptomlarının ve nedenlerinin erken evrede tanımlanması, çözümü daha da kolaylaştırmaktadır. Gelecekte görülen sırt ağrısı, bireyin geçmiş hikayesindeki sırt ağrısına ilişkin semptomları ile ilişkilidir. Özellikle oturuş postürü sırt ağrısı için önemli bir etkendir. Bireylerin oturma pozisyonlarında, lomber bölgede kifoz olmaması için kalça ekleminin yaklaşık $60^{\circ} \mathrm{C}$ eğilimli olması ve pelvis bölgesinin eğilimli olması önerilmektedir (11).

Adölesanlarda vücut duruşu problemi, sırt ağrısı gibi semptomların ölçülmesi için nicel veri elde edilen araçlar dışında nitel veri elde etmek için geliştirilen araçlar nadir bulunmaktadır. Genellikle genel ağrı ölçen araçlar ağrı değerlendirmesinde kullanılmaktadır. Türkiye'de özellikle adölesan grubuna özel sırt ağrısı ve vücut duruşu ile ilgili veri elde etmek için araçların olmadığı literatür taramasında saptanmıştır. Bu bağlamda bu araştırmada; 2013 Portekiz'de geliştirilmiş İngilizce versiyonu yapılmış Sırt Ağrısı ve Vücut Duruşu Değerlendirme Aracı'nın (Back Pain and Body Posture Evaluation Instrument (BackPEI)) Türkçe geçerlilik güvenilirliğinin değerlendirilmesi ve Türkiye'de uygulanabilirliğinin değerlendirilmesi amaçlanmıştır.

\section{Gereç ve yöntem}

Araştırmanın tipi

Bu çalışma, adölesanların sırt ağrılarını ve vücut duruşlarını değerlendirmeye yönelik "Sırt Ağrısı ve Vücut Duruşu Değerlendirme Aracı"nın ulusal hemşirelik literatürüne kazandırmak amacıyla; ölçeğin Türkçe formunun geçerlilik ve güvenilirlik çalışmasını yapmak üzere metodolojik tasarımda gerçekleştirilmiştir.

\section{Araştırmanın evren ve örneklemi}

Araştırmanın yürütüldüğü okul Ankara'da eğitim-öğretim veren bir ortaokuldur. Bu çalışmanın evrenini, belirtilen okulda 2013-2014 eğitim öğretim yılında öğrenime devam eden 468 öğrenci oluşturmuştur. Bu öğrencilerin 139 'u araştırmaya katılmıştır. Sırt Ağrısı ve Vücut Duruşu Değerlendirme Aracı'nda 20 madde bulunmaktadır. Ölçek çalışmalarında örneklem hacminin belirlenmesinde, ölçek madde sayısının 5-10 katı sayıda örnekleme ulaşılması önerilmektedir. Bu çalışmada örnekleme alınacak öğrenci sayısı $\mathrm{n}=139$ olarak belirlenmiştir.

468 öğrencinin oluşturduğu evrenden eğitim düzeylerine göre; 5 . sınıfta okuyan 101,6 . sınıfta okuyan 155,7 . sınıfta okuyan 67 ve 8 . sınıfta okuyan 145 öğrenci orantılı tabakalı örnekleme yöntemine göre dört tabakaya ayrılmıştır. Daha sonra öğrencilerin bulundukları tabakayı temsil edecek şekilde, basit rastgele örnekleme yöntemi ile sırasıyla. 5. sınıftan 30, 6.sınıftan 46, 7.sınıftan 20, 8.sınıftan 43 öğrenci belirlenmiştir.

\section{Veri toplama araçları}

Araştırmada veri toplama formu olarak, öğrencilerin davranışsal ve postural alışkanlıklarını. sırt ağrısı sıklığını belirlemek için Sırt Ağrısı ve Vücut Duruşu Değerlendirme Aracı ( BackPEI) kullanılmıştır.

Sırt Ağrısı ve Vücut Duruşu Değerlendirme Aracı (BACKPEl); Noll, Candotti, Vieira ve Loss (2012) tarafından öğrencilerin davranışsal ve postüral alışkanlıklarını, sırt ağrısı sıkIığını belirlemek amacıyla geliştirilmiş̧tir (12). Bu araç; 6 bölümden oluşmaktadır;

1) Demografik (yaş ve cinsiyet),

2) Sosyo-ekonomik statü (anne/baba eğitim düzeyi gibi sorular),

3) Davranışsal faktörler (fiziksel aktivite, yatakta okuma, televizyon izlerken ve bilgisayar başında geçirilen saat/ gün, günlük uyku saati),

4) Son üç ay içinde bel ağrısı (oluşumu, sıklığı ve yoğunluğu), 
5) Postüral faktörler (bilgisayarı kullanırken ve yazı yazarken, sırada otururken, okul malzemelerini taşıma şekli, uyku pozisyonu),

6) Genetik faktörler oluşumu (anne/baba sırt ağrısı durumu).

Vizüel (Görsel) Analog Skala (VAS): Ölçek, $100 \mathrm{~mm}$ boyunda bir yatay çizgiden ibarettir. Çizginin sol ucunda "Ağrı yok" veya "Ağrı tümüyle geçti" ibaresi yer alırken sağ ucunda ise "Dayanılmaz ağrı" veya "Ağrıda hiç azalma yok" ibaresi yer alır. Hastaya çizgi üzerinde, kendi ağrısını doğru şekilde yansıtacak bir noktayı işaretlemesi söylenir. Hastanın işaretinin sol uca uzaklığı ölçülür. Genellikle milimetre olarak ölçülen bu uzaklık "puan" olarak bildirilir. Bu çalışmada, VAS'dan alınan ağrı puanı ile vücut postür şekilleri arasında ilişki olacağı düşünülerek Sırt Ağrısı ve Vücut Duruşu Değerlendirme Aracı'nın ölçüt geçerliliğini değerlendirmek amacıyla kullanılmıştır.

\section{Uygulama}

Araştırmanın verileri araştırmacı tarafından, Mayıs 2014-Haziran 2014 tarihleri arasında gözlem altında sınıflarda yapılmıştır. Çalışmanın amacı araştırmacı tarafından öğrencilere açıklanmış ve anket sorularını eksiksiz doldurmaları hatırlatılmıştır. Ölçeğin uygulanması 20-25 dakika sürmüştür.

\section{Istatistiksel değerlendirme}

Verilerin değerlendirilmesi; sayımla belirlenen değişkenler için sayı ve yüzde ölçümle belirlenen değişkenler için ortalama \pm standart sapma ve minimum-maksimum değerler kullanılarak yapılmıştır. Ölçeğin geçerliliğini değerlendirmek amacıyla; dil geçerliliği, yapı geçerliliği ve ölçüt geçerliliği yapılmıştır.

Ölçeğin Türkçe dil geçerliliği, alanında uzman ve iyi derecede İngilizce bilen 5 öğretim üyesi tarafından Türkçe'ye çevrilmiştir. Türk dili öğretmeni tarafından gramer ve Türkçe anlaşıırlığı değerlendirilmiştir. Ölçek likert tipli bir ölçek olmaması nedeniyle yapı geçerliliğini ölçmek için yapılması gereken faktör analizi yapılmamış, verilerin faktör analizine uygunluğu Kaiser-Meyer-Olkin (KMO) katsayısı ve Bartlett Küresellik Testi yapılarak incelenmiştir. Ölçüt geçerliliğinin belirlenmesinde ise, benzer özellikleri ölçen "VAS" ile aynı gruba aynı zamanda uygulanmasından elde edilen puanlar arasındaki ilişki, Pearson korelasyon analizi ile hesaplanmıştır. Güvenilirlik çalışmasında; Cronbach alfa katsayısı, madde toplam korelasyonu ve test-tekrar test güvenilirlik katsayısı (kappa katsayısı) yapılmıştır. Test-tekrar test sonuçlarını değerlendirmek için bağımlı gruplarda t testi yapılmıştır. Veriler; \%95 güven aralığında, $p<0.05$ istatistiksel anlamlılık düzeyinde değerlendirilmiştir.

\section{Araştırmanın etik yönü}

Ölçeği geliştiren yazarlar ile internet üzerinden yazılı iletişim kurularak, Türkçe geçerlilik ve güvenirliğinin yapılması için izin alınmıştır. Araştırmanın uygulamasına; GATA Etik Kurulu'ndan “Etik Kurul Onayı" ve II Milli Eğitim Müdürlüğü ile araştırmanın uygulanacağı okuldan "Kurum İzni" alındıktan sonra başlanmıştır. Ayrıca araştırmaya katılan öğrencilerden 18 yaşından büyük olanların sözlü onamları, 18 yaşından küçük olanların ise velilerinin yazılı onamları alınmıştır.

\section{Bulgular ve tartışma}

Sosyo-demografik ve postüral faktörler

Katılımcıların yaş ortalaması 12,64 olup, $65^{\prime} \mathrm{i}$ erkektir. Araştırmaya en çok 6. sınıf (\%33.1), en az 7. sınıf (\%14.4) katılmıştır. Katılımcıların anne eğitim düzeyine bakıldığında çoğu (\%45) ortaöğretim mezunu iken, baba eğitim düzeyi en çok (\%61) üniversite mezunu olarak saptanmıştır (Tablo1).

Katılımcıların \%74.1'i düzenli spor yaptığını (erkeklerin $\% 78.5^{\prime} \mathrm{i}$; kızların \%70.3'ü) \%31'i ise haftada 5 ve daha fazla gün spor/egzersiz yaptığını bildirmiştir (erkeklerin \%26.2'si; kızların \%18.9'u). Dünya Sağlık Örgütü'nün 2010 yılındaki verilerine göre okul çağındaki 11-17 yaş arası adölesanların \%81'i yetersiz fiziksel aktivite yapmaktadır (13). Bu sonuçlar karşılaştııılığında katılımcılar genellikle düzenli spor yaptığını düşünmekte ancak DSÖ'nün adölesanlar için gerekli gördüğü günde $60 \mathrm{dk}$ fiziksel aktivite yapmamaktadırlar. Bu da okul çağındaki adölesanların birçok hastalığın, sırt ağrılarının ve postür bozukluklarının risk faktörü olan sedanter yaşam tarzına sahip olmalarına neden olmaktadır.

Katılımcıların sadece \%28.8'i 2 saatten az televizyon izlemekte olduğunu ve \%39.6'sı 2 saatten az bilgisayar kullandığını ifade etmiştir. Katılımcıların \%10.8'i yatakta ders çalıştığını, \%50.4'ü ise yatakta kitap okuduğunu bildirmiştir. Katılımcıların uyku düzeni incelendiğinde, yarısından fazlası (\%67.7) günde ortalama 7-9 saat arası uyuduğunu belirtmiş̧ir (Tablo 1). Literatürde Türkiye'de adölesanlarda giderek artan ve bir halk sağlığı sorunu hale gelen obezitenin ana nedenlerinden birisinin de ekran süresinin artması olarak bildirilmiştir (14). Mughal ve arkadaşlarının (2016) İngiltere'de 1041 adölesan ile yaptıkları çalışmada adölesanların hafta içi günde yaklaşık 
Tablo 1. Katıımcıların "Sırt Ağrısı ve Vücut Duruşu Değerlendirme Aracı"na göre bazı sosyo demografik ve davranışsal özelliklerinin dağıımı $(n=139)$

\begin{tabular}{|c|c|c|}
\hline & $n$ & $\%$ \\
\hline \multicolumn{3}{|l|}{ Cinsiyet } \\
\hline KIz & 74 & 53.2 \\
\hline Erkek & 65 & 46.8 \\
\hline \multicolumn{3}{|l|}{ Sinif } \\
\hline 5. sinif & 30 & 21.6 \\
\hline 6. sinıf & 46 & 33.1 \\
\hline 7. sınıf & 20 & 14.4 \\
\hline 8. sinif & 43 & 30.9 \\
\hline \multicolumn{3}{|l|}{ Anne eğitim } \\
\hline Okur yazar değil & 9 & 6.4 \\
\hline İlköğretim & 28 & 20.1 \\
\hline Ortaöğretim & 45 & 32.3 \\
\hline Üniversite & 57 & 41 \\
\hline \multicolumn{3}{|l|}{ Baba eğitim } \\
\hline Okur yazar değil & 1 & 0.7 \\
\hline İlköğretim & 21 & 15.1 \\
\hline Ortaöğretim & 31 & 22.3 \\
\hline Üniversite & 86 & 61.8 \\
\hline \multicolumn{3}{|l|}{ Düzenli spor/egzersiz } \\
\hline Evet & 103 & 74.1 \\
\hline Hayır & 36 & 25.9 \\
\hline \multicolumn{3}{|c|}{ Haftada kaç gün spor/egzersiz } \\
\hline Haftada 1-2 gün & 38 & 27.3 \\
\hline Haftada 3-4 gün & 41 & 29.5 \\
\hline Haftada 5 ve daha fazla & 31 & 22.3 \\
\hline Bilmiyorum, değişiyor & 29 & 20.9 \\
\hline \multicolumn{3}{|c|}{ Günde kaç saat televizyon izlersiniz } \\
\hline Günde 1 saat & 40 & 28.8 \\
\hline Günde 2-3 saat & 51 & 36.7 \\
\hline Günde 4-5 saat & 12 & 8.6 \\
\hline Günde 6-7 saat & 3 & 2.2 \\
\hline Günde 8 saatten fazla & 5 & 3.6 \\
\hline Bilmiyorum, güne bağlı & 28 & 20.1 \\
\hline \multicolumn{3}{|c|}{ Yatakta ders çalışır mısınız } \\
\hline Evet & 15 & 10.8 \\
\hline Hayır & 78 & 56.1 \\
\hline Bazı zamanlar & 46 & 33.1 \\
\hline \multicolumn{3}{|l|}{ Uyku saati } \\
\hline $0-6$ saat & 10 & 7.2 \\
\hline $7-9$ saat & 94 & 67.7 \\
\hline 10 saat ve üzeri & 35 & 25.1 \\
\hline
\end{tabular}

Tabılo 2. Katılımcıların "Bel Ağrısı ve Vücut Duruşu Değerlendirme Aracı"na göre yaşadıkları bel ağrısı ve genetik özelliklerinin dağıımı $(n=139)$

\begin{tabular}{lcc} 
& $\boldsymbol{n}$ & $\%$ \\
\hline Sırt ağrısı varlı̆ı & 69 & 49.6 \\
Evet & 61 & 43.9 \\
Hayır & 9 & 6.5 \\
Bilmiyorum & & \\
Sırt ağrısı sıklı̆ı* & 27 & 19.4 \\
Sadece bir kez & 16 & 11.5 \\
Ayda bir kez & 6 & 4.3 \\
Haftada bir kez & 15 & 10.8 \\
Haftada 2-3 kez & 13 & 9.4 \\
Haftada 4 defadan fazla & 39 & 28.1 \\
Bilmiyorum & & \\
Anne/baba bel ağrısı varlığı & 72 & 51.7 \\
Evet & 42 & 30.2 \\
Hayır & 25 & 17.9 \\
Bilmiyorum & & \\
Anne/baba bel ağrısı kimde** & 30 & 21.6 \\
Anne & 23 & 16.5 \\
Baba & 19 & \\
Her ikisi de & & \\
\hline * $n=116$ & & \\
** $n=72$ & & \\
& &
\end{tabular}

2 saat, hafta sonu ise günde yaklaşık 3 saat tv izlediklerini bildirmişlerdir (15). Bu sonuçlar bizim ülkemizde Ingiltere'ye göre daha fazla televizyon izlendiğini ve önerilen ekran süresinin üzerinde ekrana bağımlı yaşandığı düşünülebilir. Bu durum adölesanlarda postür bozukluklarına neden olabilmektedir.

Katılımcıların "Bel Ağrısı ve Vücut Duruşu Değerlendirme Aracı"na göre yaşadıkları bel ağrısı ve genetik özellikleri incelendiğinde, 49.6'sı son 3 ay içerisinde bel ağrısı yaşadığını ve \%9.4'ü sırt ağrısını haftada 4 defadan fazla hissettiklerini ifade etmişlerdir. Katılımcıların \%51.7'si anne ve/ veya babasında bel ağrısı şikayetleri olduğunu, \%13.7'sinin ise hem annesinde, hem babasında bel ağrısı şikayetleri olduğu saptanmıştır (Tablo 2). Calvo-Munoz, GomezConesa ve Sanchez-Meca (2013) tarafından yapılan metaanalizde bu çalışmaya benzer şekilde adölesanlarda bel ağrısı prevelansı 25 çalışmada \%42.4 olarak belirlenmiştir (16). Bu çalışmada, katılımcıların son 3 ayda sırt ağrısı yaşama durumu ile anne ve/veya babasının sırt ağrısı yaşama durumu karşılaştııılığında istatistiksel olarak anlamlı bir fark saptanmıştır $(p<0.05)$ (Tablo 3). Literatürde de bu sonuçlara paralel olarak bel ağrısı olan adölesanların ailesinde bel ağrısı olma durumları arasında ilişki saptanmıştır 


\begin{tabular}{|c|c|c|c|c|c|c|}
\hline & & \multicolumn{5}{|c|}{ Sırt ağrısı varlığı } \\
\hline & & Var & Yok & Bilmiyorum & $X^{2}$ & $p$ \\
\hline \multirow{3}{*}{$\begin{array}{l}\text { Anne/babada } \\
\text { sırt ağrısı varlığı }\end{array}$} & Var & 41 & 25 & 3 & & \\
\hline & Yok & 12 & 27 & 3 & 12.475 & ,014 \\
\hline & Bilmiyorum & 16 & 9 & 3 & & \\
\hline
\end{tabular}

(17). Bu bulgular, bel ağrısının genetik faktörlerden dolayı oluşabileceğini göstermektedir. Bu anlamda sırt ağrısı yaşayan ailelerin çocukları için koruyucu önlemleri alması konusunda bilinçlendirilmesi gerekmektedir.

Katılımcıların postür alışkanlıkları incelendiğinde, $\% 75.5$ okul sırasında yanlış oturma pozisyonunda otururken, $\% 65.5^{\prime} \mathrm{i}$ ise arkadaşları ile konuşurken yanlış oturduğu tespit edilmiştir. Katılımcıların yalnızca \%29.1'i bilgisayar kullanırken doğru şekilde oturduğu saptanmıştır. Eşyaları yerden doğru kaldıranların yüzdesi \%28.1 olarak saptanmıştır. Literatürde de adölesanların çoğunun otururken yanlış vücut duruşu sergiledikleri belirtilmiştir. Katılımcıların büyük çoğunluğunun (\%95) doğru okul çantası (iki tane ve yumuşak omuz askılığına sahip) kullanmakta olduğu ve \%84.2'sinin çantasını doğru şekilde taşıdığı bulunmuştur. Literatürde yazı yazarken, bilgisayarda çalışırken, yatarken yanlış vücut duruşu sergileyenler ile ağrı yaşayanlar arasında anlamlı bir ilişki saptanmıştır $(1,18)$. Bu sonuçlar doğrultusunda, adölesanların vücut ağılarının, özellikle sırt ağrılarının oluşmasını engellemek için doğru vücut duruşlarını öğrenmeleri ve uygulamaları konusunda teşvik edilmelidir. Ayrıca, okul sıra ve koltuklarının ergonomik olarak düzenlenmesi adölesanlarda yaşanan bel ağrılarının azalmasında etkili olacaktır.

Ölçek Geçerliliği: Ölçeğin geçerliliğini değerlendirmek amacıyla; dil ve kapsam geçerliliği, yapı geçerliliği ve ölçüt geçerliliği yapılmıştır (19-21).

Dil ve Kapsam Geçerliliği: Illk olarak, Sırt Ağrısı ve Vücut Duruşu Değerlendirme Aracl, iyi derecede İngilizce bilen bir ingilizce öğretmeni tarafından Türkçe'ye çevrilmiştir. Türkçe'ye çevrilen değerlendirme aracının Türk dili öğretmeni tarafından gramer ve Türkçe anlaşılırlığı değerlendirilmiştir. Daha sonra alanlarında uzman 5 öğretim üyesi (Halk Sağlığı ABD'de görevli 1 Profesör, Halk sağlığı Hemşireliği alanından 1 Doçent ve 1 Yardımc Doçent, 1 Iç Hastalıkları Hemşireliği Doçenti, 1 Çocuk Hastalıkları ve Sağlığı Hemşireliği Yardımcı Doçenti) tarafından her bir soru için görüşler alınmıştır. Uzman görüşlerinin değerlendirilmesinde Kapsam Geçerlilik Indeksi (KGI) kullanılmıştır. Bu değerlendirme aracının maddelerindeki Türkçe ifadeler, her bir sorunun sırt ağrısını ve vücut duruşunu değerlendirmedeki ilgisi ve yeterliliği, uzmanlar tarafından 1-4 arasında puanlanmıştır. Her madde için yapılan bu değerlendirmede; 1 puan=uygun değil, 2 puan=biraz uygun, 3 puan=uygun, 4 puan tamamen uygun olarak tanımlanmıştır $(22,23)$. Uzmanların değerlendirmesinde, 1 ve 2 puan verilen maddeler tekrar gözden geçirilerek düzenleme yapılmıştır. Uzman değerlendirmesi sonucunda, 6 . soruya 2 puan verildiği için tekrar gözden geçirilmiş ve "okumanı/ders çalışmanı yatağında mı yaparsın?" yerine, 2 soru şeklinde sorularak "dersini yatağında mı yaparsın?; kitabını yatağında mı okursun?" olarak düzenlenmiş̧tir. Yapılan yüzdelik hesaplamalar sonucunda $\mathrm{KGI}=90.8$ (her bir uzmanın 3 ve 4 puan verdikleri madde sayısının yüzdelik karşılıklarının ortalaması) gibi yüksek bir değer bulunmuştur. Değerlendirme aracının Türkçe son hali, bir İngilizce öğretmeni tarafından tekrar İngilizce'ye çevrilmiștir ve soruların ifadelerinde bir anlam değişikliği olmadığı tespit edilmiştir. Ölçeğin anlaşıırlığını test etmek için, çalışma evrenine benzeyen farklı 10 öğrenciye uygulama yapılmış ve anlaşılır olduğuna karar verilmiş̧ir.

Yapı Geçerliliği: Değerlendirme aracının yapı geçerliğini test etmek ve faktörleri belirlemek amacıyla açımlayıcı faktör analizi yöntemi kullanılmaktadır. Çalışma grubundan elde edilen verilerin faktör analizine uygun olup olmadığı Kaiser-Meyer-Olkin (KMO) ve Barlett testi ile açıklanabilir. KMO test değerinin 0.50 'den düşük olması faktör analizine devam edilemeyeceği şeklinde değerlendirilir (24). Barlett küresellik testi ise, ki-kare istatistik değerini vermekte; $p<0.05$ 'ten küçük anlamlılık düzeyindeki faktörleri belirlemektedir. Barlett küresellik testi anlamlılık değerinin $p>0.05$ 'ten büyük ise istenilen varyans düzeyine ulaşılmadığını ve bu nedenle ölçeğin faktör analizinin yapılamayacağını göstermektedir (22). Bu çalışmada değerlendirme aracının yapı geçerliliği için açımlayıcı faktör analizi kullanılmıştır ve KMO değeri 0.374 bulunmuştur. Bu değer, 0.50'den küçük olduğu için veri kümesinin faktör analizi için uygun olmadığını ve değerlendirme aracının faktörlere bölünemeyeceğini göstermektedir. Bu durum, Sırt Ağrısı ve Vücut Duruşu Değerlendirme Aracı'nın likert tipli bir ölçek olmadığından ve sosyo-demografik özellikleri de içeren bir anket formu olmasından kaynaklanmaktadır. Örneklem büyüklüğünün yeterliliği Bartlett Küresellik Testi ile değerlendirilmiştir ( $X=464.7, p=0.000$ ). 
Test sonucunda $p$ değerinin anlamlı çıkması örneklem sayısının yeterliliğini göstermektedir.

Ölçüt Geçerliliği: Ölçüt geçerliliği ise kullanılan ölçüm aracının ölçmeyi amaçladığı özelliği ne kadar başarıyla ölçebildiği sorusuna cevap verir (22). Bu araştırmada ölçüt geçerliliği; eş zaman geçerliliği ile değerlendirilmiştir. Karşılaştırma için "Vizüel (Görsel) Analog Skala (VAS)" kullanılmıştır. Sırt Ağrısı ve Vücut Duruşu Değerlendirme Aracındaki "Son 3 ayda yaşanan sırt ağrısı varlığı" sorusu ile VAS skoru arasındaki Spearman testi korelasyon katsayısı $r=-.684(0.60-0.70), p=.000$ olarak saptanıp iki ölçüm aracı arasında negatif yönde iyi derecede korelasyon ve anlamlı bir ilişki saptanmıştır. Bu sonuç, altın standart test olarak kabul edilen VAS skorları ile Sırt Ağrısı ve Vücut Duruşu Değerlendirme Aracı'nın ölçümlerinin ilişkili olduğunu ve bu değerlendirme aracının sırt ağrısını ölçebileceğini göstermektedir.

Ölçek Güvenirliği: Sırt Ağrısı ve Vücut Duruşu Değerlendirme Aracı'nın güvenirliği çalışması için, ilk uygulamadan iki hafta sonra farklı bir gözlemci tarafından uygulanan tekrar test ile ilk test sonuçları arasındaki uyum değerlendirilmiştir. Bu değerlendirmede, iki test arasındaki ilişkiye kappa testi ile bakılmıştır (25). Her bir sorunun test ve tekrar test karşılaştırması sonucundaki kappa puanları; 0.00-0.20=düşük ya da önemsiz uyum, $0.21-0.40=$ düşük orta düzeyde uyum, $0.41-0.60=$ orta derecede uyum, 0.61 $0.80=$ iyi derecede uyum, $0.81-1.00=$ mükemmel uyum olarak değerlendirilmiştir. Bu değerlendirme sonucunda, 3 soru "orta derecede uyum", 15 soru "iyi derecede uyum", 3 soru da "mükemmel uyum" şeklinde sınıflandırılmıştır (Tablo 4). Noll, Candotti, Vieira ve Loss (2012), Sırt Ağrısı ve Vücut Duruşu Değerlendirme Aracı'nı geliştirmek amacıyla yaptıkları çalışmalarında, bu çalışmaya benzer şekilde 8 sorunun iki ölçüm arası bulunan kappa değerleri "mükemmel uyum", 12 sorunun iki ölçüm arası bulunan kappa değerleri "iyi uyum" olarak sınıflandırılmıştır (12). 21. soru için ise Wilcoxon Signed Ranks test uygulandı. Test-tekrar test arasında farkın istatistiksel olarak anlamlı olmadığı saptanmıştır ( $Z=-.127 . p=.899)$. Bu sonuçlar, Sırt Ağrısı ve Vücut Duruşu Değerlendirme Aracı'ndan elde edilen sonuçların zaman ve gözlemci faklııı̆ından etkilenmeyeceğini ve tekrar uygulanabilir olduğunu göstermektedir.

Tablo 4. Bel Ağrısı ve Vücut Duruşu Değerlendirme Aracı'nın güvenirliği için kappa test sonuçları

\begin{tabular}{|c|c|c|c|c|}
\hline \multicolumn{2}{|c|}{ Soru Sorunun tanımı } & \multirow{2}{*}{$\begin{array}{l}\text { N } \\
91\end{array}$} & \multirow{2}{*}{$\begin{array}{c}\% \\
100\end{array}$} & \multirow{2}{*}{$\begin{array}{c}\text { Kappa testi } \\
0.726\end{array}$} \\
\hline 1 & Okulda veya okul dışında düzenli bir şekilde spor ya da egzersiz yapıyor musun? & & & \\
\hline 2 & Haftada kaç gün spor veya egzersiz yapıyorsun? & 91 & 100 & 0.647 \\
\hline 3 & Yaptığın sporla ya da egzersizle ilgili yarışmaya katıldın mı? & 91 & 100 & 0.779 \\
\hline 4 & Gün boyunca genellikle kaç saat televizyon izleyerek geçiriyorsun? & 91 & 100 & 0.667 \\
\hline 5 & Masaüstü/dizüstü bilgisayarını günde kaç saat kullanıyorsun? & 91 & 100 & 0.655 \\
\hline 6 & Dersini yatağında mı yaparsın? & 91 & 100 & 0.738 \\
\hline 7 & Kitabını yatağında mı okursun? & 91 & 100 & 0.526 \\
\hline 8 & En çok tercih ettiğiniz uyuma pozisyonu hangisidir? & 91 & 100 & 0.628 \\
\hline 9 & Bir gününüzün kaç saatini uyuyarak geçiriyorsun? & 91 & 100 & 0.500 \\
\hline 10 & Okuldaki sırada yazı yazarken genellikle nasıl oturursun? & 91 & 100 & 0.611 \\
\hline 11 & Arkadaşlarınla konuşurken genellikle sandalyeye nasıl oturuyorsun? & 91 & 100 & 0.752 \\
\hline 12 & Masaüstü/dizüstü bilgisayar kullanırken genellikle nasıl oturursun? & 91 & 100 & 0.664 \\
\hline 13 & Eşyaları yerden genellikle nasıl kaldırıyorsun? & 91 & 100 & 0.795 \\
\hline 14 & Okul çantan aşağıdakilerden hangisine benziyor? & 91 & 100 & 0.883 \\
\hline 15 & Okula giderken çantanı genellikle nasıl taşırsın? & 91 & 100 & 0.712 \\
\hline 16 & Annenin eğitim durumu nedir? & 91 & 100 & 0.857 \\
\hline 17 & Babanın eğitim durumu nedir? & 91 & 100 & 0.880 \\
\hline 18 & Anne veya babanda sırt ağrısı olur mu? & 91 & 100 & 0.670 \\
\hline 19 & Sende son 3 ayda hiç sırt ağrısı oldu mu? & 91 & 100 & 0.690 \\
\hline 20 & Eğer son 3 ayda sırt ağrısı olduysa ne sıklıkla yaşadın? & 74 & 81.3 & 0.500 \\
\hline 21 & Yaşadığın ağıı oyun oynamanı. ders çalışmanı. spor yapmanı etkiler mi/etkiledi mi? & 77 & 84.6 & 0.646 \\
\hline
\end{tabular}




\section{Sonuç ve öneriler}

Bu çalışmada Sırt Ağrısı ve Vücut Duruşu Değerlendirme Aracı́nın (Back Pain and Body Posture Evaluation Instrument (BackPEI)) Türkçe geçerlilik ve güvenirliği test edilmiştir. Test sonuçları Sırt Ağrısı ve Vücut Duruşu Değerlendirme Aracı'nın geçerlik ve güvenirliğinin yeterli olduğunu göstermiş̧tir. Adölesanlarda sırt ağrısı ve vücut duruşunu, ağrı ve postür için yapılan girişimlerin

\section{Kaynaklar}

1. Noll M, Candotti CT, Rosa BN, Schoenell MCW, Tiggemann CL, Loss JF. Back Pain and The Postural and Behavioral Habits of Students in The Municipal School Network of Teutônıa, Rıo Grande Do Sul. Journal of Human Growth and Development 2013; 23: 129-35. [CrossRef]

2. Hoy D, Brooks P, Blyth F, Buchbinder R. The Epidemiology of Low Back Pain. Best Prac Res Clin Rheumatol. 2010;24:769-81. [CrossRef]

3. Morris SL, O'Sullivan PB, Murray KJ, Bear N, Hands B, Smith AJ. Hypermobility and Musculoskeletal Pain in Adolescents. J Pediatr 2017; 181: 213-21. [CrossRef]

4. WeiGuang Y, Luo C, Ai F, Chen Q. Risk Factors for Nonspecific LowBack Pain in Chinese Adolescent: A Case-Control Study. Pain Medicine 2012; 13: 658-64. [CrossRef]

5. Kayıran S, Kayıran SM. Çocuklarda Bel Ağrısı. TAF Preventive Medcine Bulletin 2011;10:115-18.

6. Demir YP, Çırak Y, Dalkılınç M, Yılmaz GD, Uraş İ, Kömürcü M. İlkokul Çocuklarında Çanta Taşıma, Bilgisayar Kullanma Alışkanlığı ve Postür. Ankara Medical Journal 2012;12:182-7.

7. Geldhof E, Cardon G, De Bourdeaudhuij I, De Clercq D. Effects of a Two-School-Year Multifactorial Back Education Program in Elementary Schoolchildren. Spine 2006; 31:1965-73. [CrossRef]

8. Widhe T., Spine: Posture, Mobility and Pain. Alongitudinal study from childhood to adolescence. Europe Spine Journal 2001;10:118-23. [CrossRef]

9. Cardon G, De Clerq D, Bourdeaudhuij ID, Breithecker D. Sitting habits in elementary schoolchildren: a traditional versus a "Moving school". Patient Education and Counseling 2004; 54: 133-42. [CrossRef]

10. Yao W, Luo C, Ai F, Chen Q. Risk Factors for Nonspecific Low-Back Pain in Chinese Adolescents: A Case-Control Study. Pain Medicine. 2012;13: 658-64. [CrossRef]

11. Murphy S, Buckle P, Stubbs D. Classroom Posture and Self-Reported Back and Neck Pain in Schoolchildren. Applied Ergonomics. 2004;35:113-20. [CrossRef]

12. Noll M, Tarragô Candotti C, Vieira A, Fagundes Loss J. Back Pain and Body Posture Evaluation Instrument (BackPEI): Development. Content Validation and Reproducibility. International Journal of Public Health 2012;58:565-72. [CrossRef] etkinliğini değerlendirmek için Sırt Ağrısı ve Vücut Duruşu Değerlendirme Aracı kullanılabilir. Ayrıca Sırt Ağrısı ve Vücut Duruşu Değerlendirme Aracı adölesanların ağrısının ilişkili olabileceği faktörleri saptamak için de kullanılabilir. Bu değerlendirme aracı, adölesanlar üzerinde geliştirildiğinden ve test edildiğinden dolayı, farklı örneklem gruplarında kullanabilmek için, o örnek gruplarında geçerliği ve güvenirliği test edildikten sonra uygulanabilir.

13. Dünya Sağlık Örgütü, DSÖ (2010). Global Recommendations On Physical Activity For Health. http://apps.who.int/iris/ bitstream/10665/44399/1/9789241599979_eng.pdf Erişim tarihi: 22 May 2019

14. Barbaros H, Balcı S. Küreselleşen Dünyada Çocuklarda Büyüyen Sorun: Obezite. Yıldırım Beyazıt Üniversitesi Hemşirelik E-Dergisi 2015; 3: 38-46.

15. Mughal S, Sherar LB, Griffiths $P$, Bodicoat $D H$, Harrington DM, Edwards RT, et al. Self-Reported Domain Specific Sedentary Behaviours in A South Asian and White British Sample of UK Girls. Pediatric Exercise Science 2016; 28: 55.

16. Calvo-Munoz I, Gómez-Conesa A, Sánchez-Meca J. Prevalence of low back pain in children and adolescents: a meta-analysis. BMC Pediatrics 2013; 13:14. [CrossRef]

17. Caneiro JP, Labie C, Sulley E, Briggs AM, Straker LM, Burnett AF et al. An Exploration of Familial Associations of Two Movement PatternDerived Subgroups of Chronic Disabling Low Back Pain; A CrossSectional Cohort Study. Manual Therapy 2016; 22: 202-10. [CrossRef]

18. Womersley L, May S. Sittıng Posture of Subjects With Postural Backache, Journal of Manipulative and Physiological Therapeutics 2006; 29: 213-8. [CrossRef]

19. Alpar R. Uygulamalı İstatistik ve Geçerlik-Güvenirlik. 2. Baskı. Ankara: Detay Yayıncılık. 2012; 416-20; 488-98.

20. Büyüköztürk Ş. Veri analizi el kitabı. 17. Baskı. Ankara; Pegema Yayınevi. 2012; 167-70.

21. Tekin $\mathrm{H}$. Eğitimde ölçme ve değerlendirme. Gözden geçirilmiş 14. Baskı. Ankara: Yargı yayınları. 2009; 54-6.

22. Erdoğan S, Nahcivan N, Esin NM. Hemşirelikte Araştırma Süreç, Uygulama ve Kritik. Veri Toplama Yöntem ve Araçları \& Veri Toplama Araçlarının Güvenirlik ve Geçerliği. 1. Baskı İstanbul: Nobel Tıp Kitabevleri; 2014; 193-233.

23. Polit DF, Beck CT. The Content Validty Index: Are You Sure You Know What's Being Reported? Critigue and Recomendations. Res Nurs Health 2006; 29: 489-97. [CrossRef]

24. Yong AG, Pearce S. A Beginner's Guide to Factor Analysis: Focusing on Exploratory Factor Analysis. Tutorials in Quantitative Methods for Psychology 2013; 9: 79-94. [CrossRef]

25. Kılıç S. Kappa testi. Journal of Mood Disorders. 2015; 5: 142-44. [CrossRef] 